\title{
Obituaries
}

\section{Dr Sheila Mann FRCPsych}

Formerly Senior Lecturer at St Bartholomew's Hospital and Consultant in the Psychiatry of Old Age to the North East Essex Mental Health Trust (now the East London Foundation Trust)

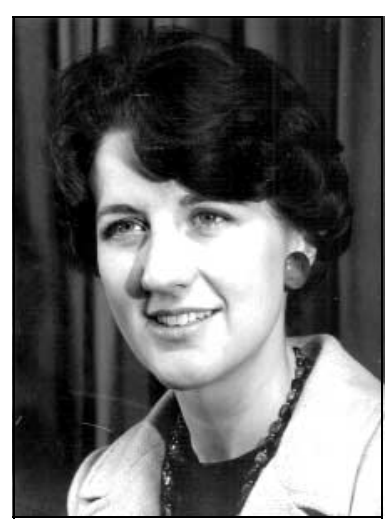

Sheila Mann was a leading figure in the Royal College of Psychiatrists, holding positions of major responsibility within the College from the 1970s for over 35 years. She joined the Research Committee in 1973, becoming its Honorary Secretary in 1977 and chairman of its first in-house research project: a national audit of the use of electroconvulsive therapy. She was Sub-Dean from 1979 to 1984 when she joined the Board of Examiners, the body to which she made her most important contribution. She was appointed Deputy Chief Examiner in 1990 and was rapidly promoted to take on the highly responsible and onerous role of Chief Examiner in 1991. Later she became the College Revalidation Lead (1999-2003) and was Vice President with special responsibility for clinical governance from 2000 to 2002 . Sheila was awarded the College's highest honour, the Honorary Fellowship, in 2007.

Sheila's work was not limited to the College. She made a major contribution to the General Medical Council (GMC), where she was an examiner and assessor on its Health Committee for 12 years and a health screener for 8 years. She became chairman of the Working Group on Assessment in Psychiatry, devising a procedure for the assessment of psychiatrists whose competence was in question. She served as an appointed member of the GMC for 6 years and on the Overseas and Registration committees for 6 years. This led to her becoming the GMC representative on the Working Group on New Roles for Psychiatrists and the Specialist Training Authority.

Sheila was born in Redditch, Worcestershire, on 5 June 1942. She went to King Edward VI High School for Girls in Birmingham and then to Birmingham Medical School. She graduated with honours in 1965 with distinctions in medicine, surgery and obstetrics, and several prizes. As a recognised high flyer she was expected to become a cardiologist. Sheila had other ideas. After her house jobs she did a short locum in general practice before becoming one of the first senior house officers for Professor Trethowan and Dr Cawley in the newly formed Department of Psychiatry at Birmingham. A year later (1967) she obtained a place on the Maudsley rotation. In 1972, she joined the staff of the Social Psychiatry Section in the Institute of Psychiatry, King's College London where she met her husband John Leach. Her research was concerned with the so-called 'new long-stay' patients and the Present State Examination.

In 1981, she moved to the Psychiatry Department in the University of Bristol, where she studied the psychiatric problems of members of the National Survey of Health Development and her husband John became a medical student in Bristol. Bristol was also the place she took up her first post in psychogeriatrics, her lifelong clinical work. Sheila and John returned to the London area in 1986, when she was appointed Senior Lecturer at St Bartholomew's Hospital Medical School and Consultant in the Psychiatry of Old Age to the North East Essex Mental Health Trust. She retired from these posts in July 2007. She was an acknowledged national expert on the psychiatry of old age and served as medical director of her trust.

It is difficult to think of anyone who gave so much dedicated service to the medical and psychiatric professions with so little self-promotion. She might well have become president of the Royal College of Psychiatrists but chose not to go down that path. She had dedication to the public good and unassuming modesty. Sheila was a rare and remarkable role model for the next generation of psychiatrists. She was a very private person but a delightful friend who enjoyed life immensely. She was discreet about her passion for fast cars. She loved animals, particularly her cats and 14 sheep (each with their own name), travel, music and her garden.

I knew Sheila Mann from her student days and worked with her on many important topics within the College. It was a privilege to do so. She has left a significant void in British psychiatry and many of us will miss her wisdom, sense of fun and delightful company for many years to come. It is one of life's cruel ironies that the Alzheimer's disease which overtook her mother and which she herself feared did indeed rob her of the long retirement she so richly deserved.

At her funeral her husband, Dr John Leach, described Sheila as one of the most distinguished psychiatrists of her generation. Mike Shooter, in his citation when she was awarded the Honorary Fellowship of the Royal College of Psychiatrists, described her as 'the personification of wisdom'. Those who knew her well regard both those statements as amply justifiable.

Sheila Mann died on 31 March 2013 and is survived by her husband John.

John Gunn

doi: $10.1192 /$ pb.bp.113.045807 